\title{
STATISTICAL ANALYSIS OF WIND SPEED DISTRIBUTION OF TURKEY AS REGIONAL
}

\author{
Ebru Kavak Akpinar ${ }^{1 *}$, Sinan Akpinar ${ }^{2}$, Nilay Balpetek ${ }^{1}$ \\ ${ }^{1}$ Department of Mechanical Engineering, Faculty of Engineering, \\ Firat University, 23279, Elaziğ, Turkey, \\ ebruakpinar@firat.edu.tr (correspondingauthor) \\ ${ }^{2}$ Department of Physics, Faculty of Science \\ Firat University, 23279, Elaziğ \\ sakpinar@firat.edu.tr
}

\begin{abstract}
In this study, the statistical analysis of wind power density and wind speed distribution parameters of the selected cities from seven region of Turkey was investigated using the hourly wind speed data measured by the Turkish State Meteorological Service between 2005 and 2014. The Weibull and Rayleigh distributions were used for modeling and the success of this modeling process was evaluated according to the criterias of $\mathrm{R}^{2}$, RMSE and $\chi^{2}$. The Weibull parameters and the Rayleigh parameters were estimated analytically, and the mean wind speed and energy potential were determined based on these parameters. At the Weibull distribution, the lowest mean wind speed and power density was obtained as $1.73 \mathrm{~m} / \mathrm{s}$ and $5.78 \mathrm{~W} / \mathrm{m}^{2}$ in Adiyaman, respectively. The highest mean speed and power density was determined as $2.95 \mathrm{~m} / \mathrm{s}$ and $33.32 \mathrm{~W} / \mathrm{m}^{2}$ in Sinop. At the Rayleigh distribution, the lowest and the highest mean speed and the power density was obtained as $1.72 \mathrm{~m} / \mathrm{s}$ and $5.63 \mathrm{~W} / \mathrm{m}^{2}$ in Adiyaman, $3.06 \mathrm{~m} / \mathrm{s}$ and $33.44 \mathrm{~W} / \mathrm{m}^{2}$ in Sinop, respectively. Generally, the highest mean wind speed and power density values were determined in Sinop, and the lowest mean wind speed and power density values in Adryaman. According to statistical criteria in wind data analysis of Turkey, the Weibull distribution was better than the Rayleigh distribution.
\end{abstract}

Keywords: Wind energy, statistically analysis of the wind energy potential, Weibull distribution, Rayleigh distribution, Turkey

\section{Introduction}

Wind energy is regarded as a clean energy resource for the environment with its renewable characteristic. It does not require any sort of transportation or high technology. Renewable wind energy has some other advantages as well. It is abundant and free in the atmosphere, and 
is a clean energy resource, which is easy to obtain and creates no environmental pollution. Energy is also primary element of economic and social development in the world. Developed and developing countries tend to include the use of renewable energy resources into their future plans. These countries develop new technology in this field and increase their investment in order to utilize their potential more effectively. The world will use renewable energy instead of using fossil fuels in order to meet the demands of the world's energy [1].

Theoretically, yearly wind potential of Turkey is very big, which is about twice as much as the current electricity consumption of country. Turkey's technical wind energy potential is $88,000 \mathrm{MW}$ and its economic wind energy potential is about 10,000 MW. According to the reports of State Electrical Studies Board, wind energy potential of Turkey is estimated as around 120 billion $\mathrm{kWh}$. Studies have showed that total wind energy potential of Turkey is higher than its present thermal and hydraulic energy production. In Turkey, the available wind energy power was 433.35 MW by the end of the year 2008; and it became1503.35 MW at the end of 2010. The strong development of wind energy in Turkey is expected to be continued in coming years. After all, it can be concluded that wind energy generation locations in Turkey are all at low altitudes [2].

In general, wind power prediction methods are categorized into two groups: physical and statistical. The first one implies physical considerations such as topography, terrains, local temperature and pressure to estimate the wind field more accurately and, subsequently, the energy potential. The later one, on the other hand, use statistical models in order to establish the relationship between power and other variables as well as their historical and forecasted values. Weibull distribution provides better fit to probability distributions compared to Rayleigh model and analyzes the wind speed data by using statistical distributions. The Weibull distribution (named after the Swedish physicist W. Weibull, who applied it when studying material strength in tension and fatigue in the 1930s) provides a close approximation to the probability laws of many natural phenomena. It has been used to represent wind speed distributions for application in wind loads studies for some time. For more than half a century the Weibull distribution has attracted the attention of statisticians working on theory and methods as well as various fields of statistics [3]. In this context, over the last decade, some researchers have performed the assessments of wind power in Turkey on the basis of individual locations [4-18]. The wind energy density in many provinces and localities of Turkey; Bilecik [4, 5], the western coast of Anatolia [6], Izmir [7], Iskenderun [8], Nurdağ1Gaziantep [9], Kütahya [10], Maden-Elazığ [11], Agın-Elazığ [12], Keban-Elazığ [13], Elazig and its close regions [14], Akşehir-Konya [15], Kurklareli [16], Maden, Gokceada, Canakkale and Bozcaada [17], Antakya[18], investigated and statistically analyzed using Weibull and Rayleigh distributions. Two parameter Weibull distribution is used to model of many regions of Turkey wind speed in recent year. The reason of using this method is very good fit wind distribution $[4,7,19]$.

Turkey is a country surrounded by the sea on three sides, connecting Asia and Europe and therefore having a strategic position. The aim of this study was to calculate the wind energy potential of the selected cities from the seven region of Turkey and to assess the efficiency of electricity production by using the wind data recorded at the meteorological station. 


\section{Wind speed data}

There are 7 regions in Turkey. They are split into climate, location, human activities/communication, etc. Turkey is bounded by four seas on three sides, spans a relatively large region in Asia and Europe. Four regions were named after the seas bordering them the Aegean, Black Sea, Marmara and Mediterranean. Three regions were named in accordance with their location in the whole of Anatolia; Central, Eastern and Southeastern.

The wind data used in this study were measured and recorded hourly at the stations of the Turkish State Meteorological Service at $10 \mathrm{~m}$ above ground level between 2005 and 2014. The details of the studied cities (Adiyaman, Bursa, Elazı ̆̆ İskenderun, Karaman, Muğla and Sinop) from seven regions of Turkey is given Figure 1 and Table 1. The wind data were captured using a cup generator anemometer.

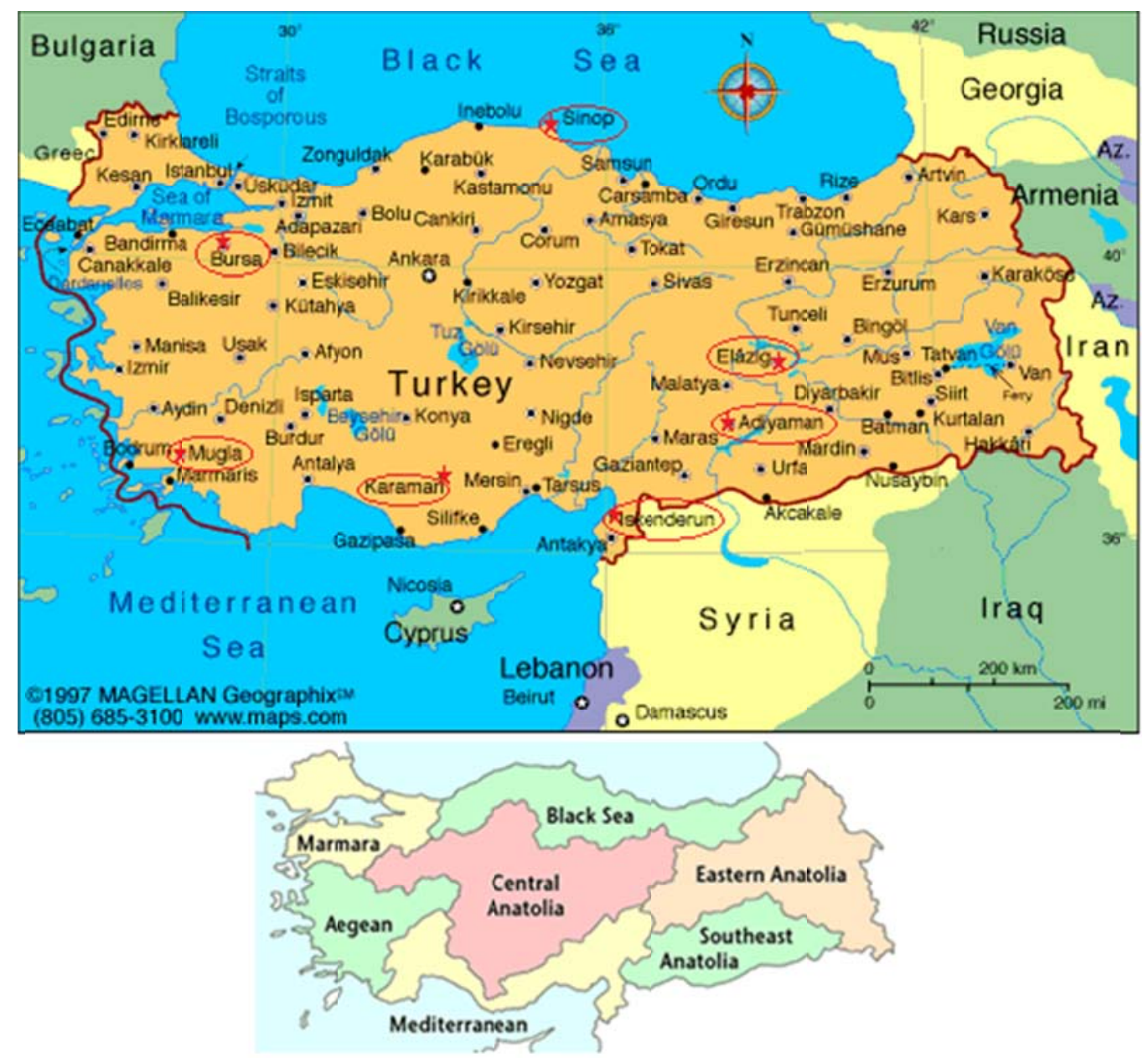

Figure 1. Location of the studied cities on Turkey map 
Table 1. The details of the studied cities

\begin{tabular}{ccccc}
\hline Station & Region & Latitude-Longitude & $\begin{array}{l}\text { Height of ground } \\
\text { above sea level }(\mathbf{m})\end{array}$ & $\begin{array}{l}\text { Air density } \\
\left(\mathbf{k g} / \mathbf{m}^{3}\right)\end{array}$ \\
\hline Adıyaman & Southeastern Anatolia & $38^{\circ} 17^{\prime} \mathrm{N}-37^{\circ} 46^{\prime} \mathrm{E}$ & 669 & 1.145 \\
Bursa & Marmara & $40^{\circ} 15^{\prime} \mathrm{N}-29^{\circ} 05^{\prime} \mathrm{E}$ & 100 & 1.213 \\
Elazı̆ & Eastern Anatolian & $38^{\circ} 37^{\prime} \mathrm{N}-39^{\circ} 14^{\prime} \mathrm{E}$ & 1015 & 1.104 \\
Iskenderun & Meditteranean & $36^{\circ} 32^{\prime} \mathrm{N}-36^{\circ} 10^{\prime} \mathrm{E}$ & 3 & 1.224 \\
Karaman & Central Anatolian & $37^{\circ} 14^{\prime} \mathrm{N}-33^{\circ} 13^{\prime} \mathrm{E}$ & 1250 & 1.076 \\
Muğla & Aegean & $37^{\circ} 15^{\prime} \mathrm{N}-28^{\circ} 22^{\prime} \mathrm{E}$ & 646 & 1.148 \\
Sinop & Balack Sea & $42^{\circ} 01^{\prime} \mathrm{N}-35^{\circ} 11^{\prime} \mathrm{E}$ & 32 & 1.221 \\
\hline
\end{tabular}

\section{Theory of wind speed and wind power}

There are several continuous probability density functions that can be used to model the wind speed frequency curve by fitting long time series measured data. In wind power studies, the Weibull and Rayleigh probability density functions are commonly used and widely adopted [4-19]. Herein the Weibull distribution is used since the Rayleigh distribution is only a subset of it.

\subsection{Weibull and Rayleigh distribution of wind speed}

The probability denstiy function of Weibull distribution that is a special case of generalized gamma distribution for wind speed is expressed with Eq. (1).

$$
f_{w}(v)=\left(\frac{k}{c}\right)\left(\frac{v}{c}\right)^{k-1} \exp \left(-\left(\frac{v}{c}\right)^{k}\right)
$$

where $f_{w}(v)$ is the probability of observing wind speed $v, k$ the dimensionless Weibull shape parameter and $c$ the Weibull scale parameter, which has its reference value in the units of wind speed [4-18].

The cumulative distribution function of the Weibull distribution is calculated as below [7, 11]:

$$
F_{w}(v)=1-\exp \left(-\left(\frac{v}{c}\right) k\right)
$$

Determination of the parameters of the Weibull distribution requires a good fit of Equation (2) to the recorded discrete cumulative frequency distribution. Taking the natural logarithm of both sides of Eq. (2) twice, gives

$$
\ln \{-\ln [1-F(v)]\}=k \ln (v)-k \ln c
$$


So, a plot of $\ln \{-\ln [1-F(v)]\}$ versus $\ln v$ presents a straight line. The gradient of the line is $k$ and the intercept with the $y$-axis is $-k \ln c$.

The $k$ values range from 1.5 to 3.0 for most wind conditions. Another distribution function used in determination of the wind speed potential is Rayleigh distribution. This distribution is a special case of Weibull distribution and validate situation where the dimensionless shape parameter $\mathrm{k}$ of the Weibull distribution is assumed to be equal to 2. Probability density and cumulative function of the Rayleigh distribution are given by Eqs. (4) and (5), respectively,

$$
\begin{gathered}
f_{R}(v)=\left(\frac{2 v}{c^{2}}\right) \exp \left(-\left(\frac{v}{c}\right)^{2}\right) \\
F_{R}(v)=1-\exp \left(-\left(\frac{v}{c}\right)^{2}\right)
\end{gathered}
$$

The mean $v_{\mathrm{m}}$ and standard deviation $\sigma$ of the Weibull distribution can then be computed from,

$$
\begin{gathered}
v_{m}=c \Gamma\left(1+\frac{1}{k}\right) \\
\sigma=\sqrt{c^{2}\left\{\Gamma\left(1+\frac{2}{k}\right)-\left[\Gamma\left(1+\frac{1}{k}\right)\right]^{2}\right\}}
\end{gathered}
$$

where $\Gamma()$ is the gamma function [7].

Based on the Weibull distribution, the wind speed with the largest frequency is calculated from Eq. (8)

$$
V_{\text {mod }}=c\left(1-\frac{1}{k}\right) 1 / k
$$

The maximum wind speed is given by [14]:

$$
V_{\max E}=c\left(\frac{k+2}{k}\right) 1 / k
$$

When $k=2$ is taken in the above formulas, calculations are performed for Rayleigh distribution [4-18].

\subsection{Calculations of wind power}

The wind power per unit area in any windy site is of importance in assessing of the wind power projection for the power plants. The mean wind power density of the considered site per unit area based on any probability density function can be expressed as [16],

$$
P_{m}=\int_{0}^{\infty} P(v) f(v) d v
$$


It is well known that the power of the wind that flows at speed $v$ through a blade sweep area $\mathrm{A}$ increases as the cubic of its velocity and is given by

$$
P(v)=\frac{1}{2} \rho A v^{3}
$$

where $\rho$ is the air density for the studied site. The mean power density for the Weibull distribution is obtained from Eq. (12) as follows

$$
P_{w}=\frac{1}{2} \rho c^{3} \Gamma\left(1+\frac{3}{k}\right)
$$

where, $\Gamma$ is gamma function.

The mean power density for the Rayleigh distribution is determined by Eq. (13):

$$
P_{R}=\frac{3}{k} \rho v^{3} m
$$

\subsection{Statistical analysis of distributions}

The coefficient of determination $\left(R^{2}\right)$, chi-square $\left(\chi^{2}\right)$ and root mean square error analysis $(R M S E)$ and were used as the primary criterion to select the best distribution to account for the variation in the wind speed curves. Chi-square is the mean square of the deviations between the experimental and calculated values for the distributions and was used to determine the goodness of the fit. The lower are the values of chi-square, the better is the goodness of the fit. The RMSE gives the deviation between the predicted and experimental values, and it is required to approach zero. The $\mathrm{R}^{2}$ also gives the ability of the model, and its highest value is 1 . These statistical values can be calculated as follows:

$$
\begin{gathered}
R^{2}=\frac{\sum_{i=l}^{N}(y i-z i)^{2}-\sum_{i=l}^{N}(x i-y i)^{2}}{\sum_{i=l}^{N}(y i-z i)^{2}} \\
x^{2}=\frac{\sum_{i=l}^{N}(y i-x i)^{2}}{N-n} \\
R M S E=\left[\frac{1}{N} \sum_{i=l}^{N}(y i-x i)^{2}\right]^{1 / 2}
\end{gathered}
$$

where $y i$ is the $i$ th experimental data, $z i$ is the mean value of the experimental data, $x i$ is the $i t h$ predicted data with the Weibull or Rayleigh distribution, $N$ is the number of observations and $n$ is the number of constants [11-14]. 


\section{Results and discussion}

In this study, wind speed data in the selected cities from seven region of Turkey, over a tenyear period from 2005 to 2014 were analyzed. Based on these data, wind speeds analysed were processed using Statistica statistical software and Fortran computer software. Calculations in the whole regions were then made to obtain the Weibull and Rayleigh distribution parameters in terms of $k$ and $c$, mean wind speed and mean wind power. The main results obtained from the present study can be summarized as follows:

The monthly mean wind speeds are illustrated in Figure 2. Table 2 shows the maximum and minimum values of the monthly mean wind speed and also the yearly mean values for the period of 2005 and 2014. The monthly and yearly mean wind speed values are mostly between 1.0 and $4.0 \mathrm{~m} / \mathrm{s}$ for the selected cities. The maximum value of the yearly mean wind speed is $3.36 \mathrm{~m} / \mathrm{s}$ in Sinop while the minimum value is $1.97 \mathrm{~m} / \mathrm{s}$ in Adiyaman. In Elazı̆g, Muğla, Karaman and Bursa, the mean wind speed is mostly on $2 \mathrm{~m} / \mathrm{s}$ and wind energy potential is suitable for wind energy applications. In Iskenderun and Sinop, it is determined that electricity generation from wind energy is suitable because the monthly mean speed is mostly on $3 \mathrm{~m} / \mathrm{s}$. In Adiyaman, the monthly mean wind speed is about $2 \mathrm{~m} / \mathrm{s}$, is not suitable for wind energy applications.

Table 2. The monthly and yearly mean wind speed values for the studied cities

\begin{tabular}{|c|c|c|c|}
\hline $\begin{array}{l}\text { The monthly mean wind } \\
\text { speeds }\end{array}$ & The minimum & The maximum & $\begin{array}{l}\text { The yearly mean wind } \\
\text { speeds }\end{array}$ \\
\hline Adıyaman & $\begin{array}{l}1.34 \mathrm{~m} / \mathrm{s} \text { in January of } \\
2014\end{array}$ & $3.09 \mathrm{~m} / \mathrm{s}$ in June of 2008 & $1.97 \mathrm{~m} / \mathrm{s}$ \\
\hline Bursa & $\begin{array}{l}1.50 \mathrm{~m} / \mathrm{s} \text { in November of } \\
2006\end{array}$ & $\begin{array}{l}3.78 \mathrm{~m} / \mathrm{s} \text { in August of } \\
2013\end{array}$ & $2.53 \mathrm{~m} / \mathrm{s}$ \\
\hline Elazı $\breve{g}$ & $\begin{array}{l}2.18 \mathrm{~m} / \mathrm{s} \text { in October } 2009 \\
\text { as }\end{array}$ & $3.85 \mathrm{~m} / \mathrm{s}$ in March 2012 & $2.83 \mathrm{~m} / \mathrm{s}$ \\
\hline İskenderun & $\begin{array}{l}1.68 \mathrm{~m} / \mathrm{s} \text { in November of } \\
2012\end{array}$ & $4.5 \mathrm{~m} / \mathrm{s}$ in July of 2006 & $2.82 \mathrm{~m} / \mathrm{s}$ \\
\hline Karaman & $\begin{array}{l}1.77 \mathrm{~m} / \mathrm{s} \text { in November } \\
2011\end{array}$ & $3.91 \mathrm{~m} / \mathrm{s}$ in March 2008 & $2.64 \mathrm{~m} / \mathrm{s}$ \\
\hline Muğla & $\begin{array}{l}1.39 \mathrm{~m} / \mathrm{s} \text { in March of } \\
2013\end{array}$ & $\begin{array}{l}2.84 \mathrm{~m} / \mathrm{s} \text { in February of } \\
2005\end{array}$ & $2.23 \mathrm{~m} / \mathrm{s}$ \\
\hline Sinop & $\begin{array}{l}2.41 \mathrm{~m} / \mathrm{s} \text { in March of } \\
2013\end{array}$ & $\begin{array}{l}4.28 \mathrm{~m} / \mathrm{s} \text { in February of } \\
2011\end{array}$ & $3.36 \mathrm{~m} / \mathrm{s}$ \\
\hline
\end{tabular}




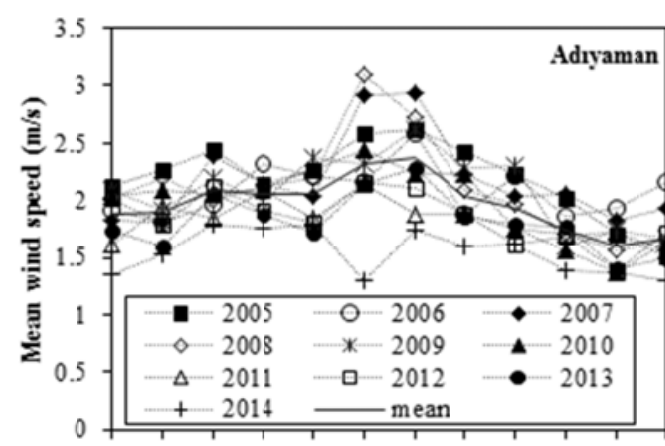

3.

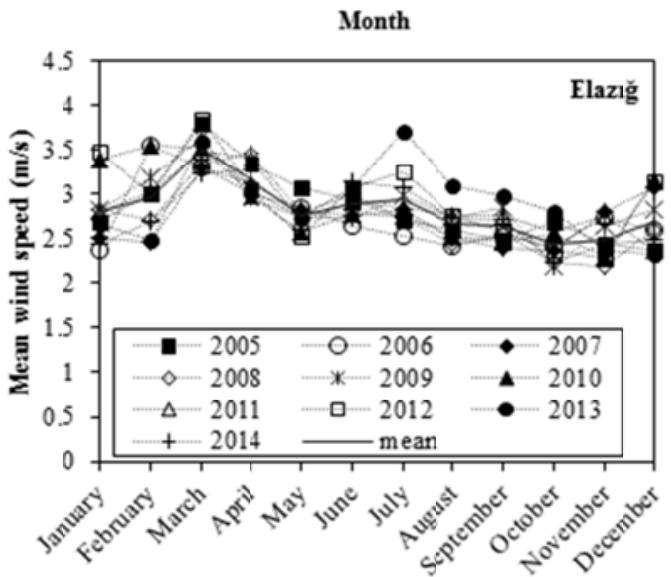

Month

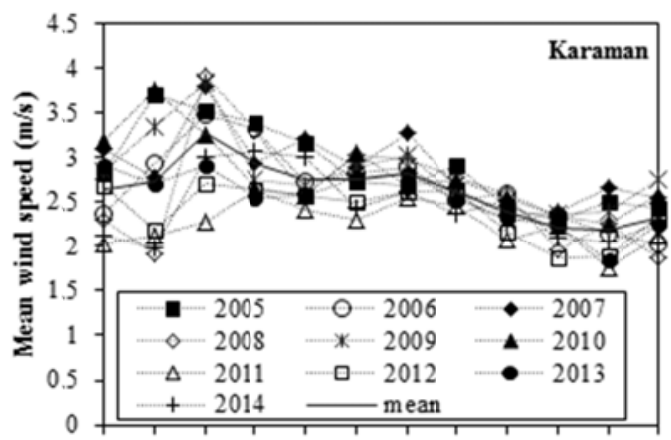

10

Month

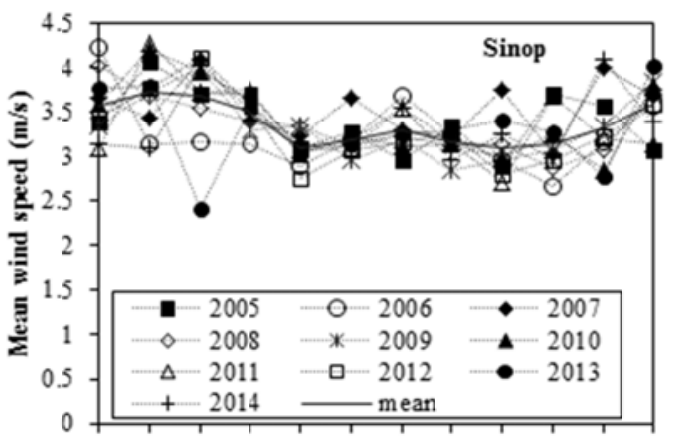

की

Month

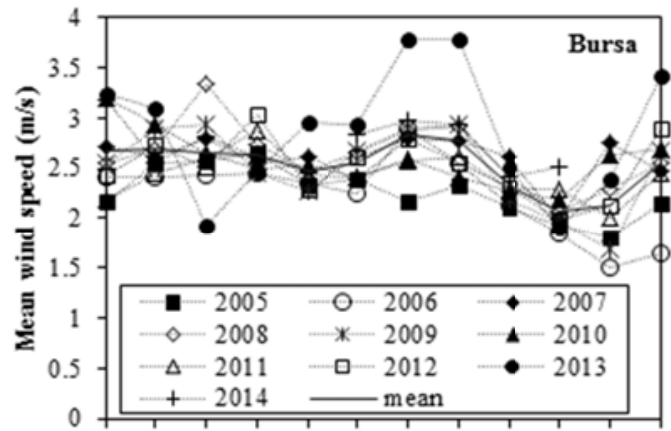

10

Month

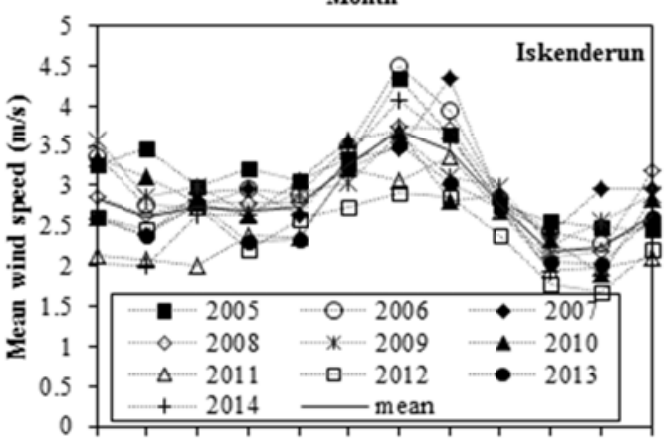

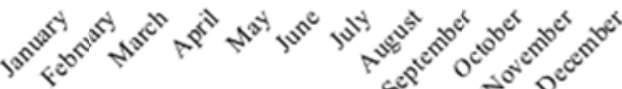

Month

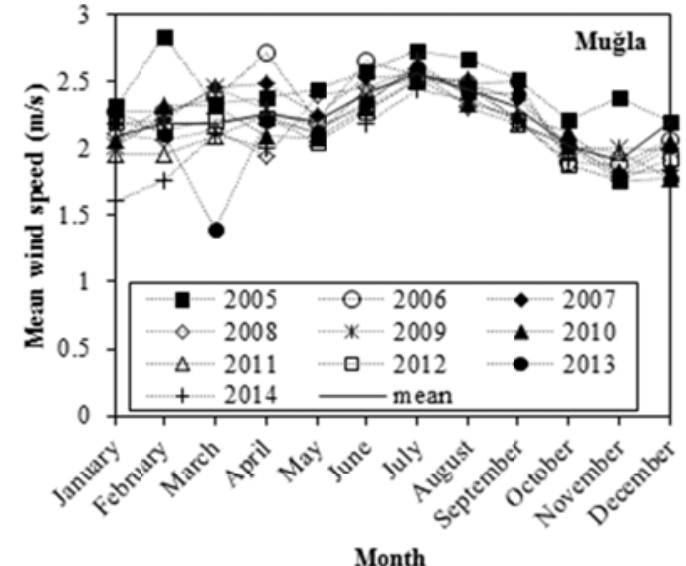

Figure 2. Monthly mean wind speed for the period of 2005-2014 
In Figure 3, the diurnal variation of mean wind speed values is plotted. The lowest and highest mean wind speed values at the diurnal variation are given Table 3 . According to the yearly average results, the wind speed is the lowest in Adiyaman, and is the highest in Sinop. The diurnal wind speed has its minimum during the morning hours and its maximum during the afternoon hours.

Table 3. The diurnal variation of mean wind speed

\begin{tabular}{|c|c|c|c|}
\hline $\begin{array}{l}\text { The diurnal variation of } \\
\text { mean wind speed }\end{array}$ & The lowest & The highest & $\begin{array}{l}\text { The mean of } \\
\text { whole year }\end{array}$ \\
\hline Adıyaman & $\begin{array}{l}0.59 \mathrm{~m} / \mathrm{s} \text { between the hours of } \\
04: 00 \text { and } 05: 00 \text { in } 2014 \text { year }\end{array}$ & $\begin{array}{l}2.29 \mathrm{~m} / \mathrm{s} \text { between the hours of } \\
14: 00 \text { and 15:00 in } 2005 \text { year. }\end{array}$ & $1.48 \mathrm{~m} / \mathrm{s}$ \\
\hline Bursa & $\begin{array}{l}0.97 \mathrm{~m} / \mathrm{s} \text { between the hours of } \\
05: 00 \text { and 06:00 in } 2005 \text { year }\end{array}$ & $\begin{array}{l}3.71 \mathrm{~m} / \mathrm{s} \text { between the hours of } \\
14: 00 \text { and 15:00 in } 2013 \text { year. }\end{array}$ & $2.06 \mathrm{~m} / \mathrm{s}$ \\
\hline Elazı̆̆ & $\begin{array}{l}1.47 \mathrm{~m} / \mathrm{s} \text { between the hours of } \\
06: 00 \text { and } 07: 00 \text { in } 2014 \text { year }\end{array}$ & $\begin{array}{l}3.35 \mathrm{~m} / \mathrm{s} \text { between the hours of } \\
14: 00 \text { and 15:00 in } 2009 \text { year. }\end{array}$ & $2.36 \mathrm{~m} / \mathrm{s}$ \\
\hline İskenderun & $\begin{array}{l}1.08 \mathrm{~m} / \mathrm{s} \text { between the hours of } \\
04: 00 \text { and } 05: 00 \text { in } 2012 \text { year }\end{array}$ & $\begin{array}{l}3.81 \mathrm{~m} / \mathrm{s} \text { between the hours of } \\
14: 00 \text { and 15:00 in } 2005 \text { year. }\end{array}$ & $2.35 \mathrm{~m} / \mathrm{s}$ \\
\hline Karaman & $\begin{array}{l}0.89 \mathrm{~m} / \mathrm{s} \text { between the hours of } \\
07: 00 \text { and } 08: 00 \text { in } 2006 \text { year }\end{array}$ & $\begin{array}{l}3.55 \mathrm{~m} / \mathrm{s} \text { between the hours of } \\
15: 00 \text { and 16:00 in } 2005 \text { year. }\end{array}$ & $2.04 \mathrm{~m} / \mathrm{s}$ \\
\hline Muğla & $\begin{array}{l}1.12 \mathrm{~m} / \mathrm{s} \text { between the hours of } \\
22: 00 \text { and 23:00 in } 2014 \text { year }\end{array}$ & $\begin{array}{l}2.82 \mathrm{~m} / \mathrm{s} \text { between the hours of } \\
13: 00 \text { and 14:00 in } 2005 \text { year. }\end{array}$ & $1.74 \mathrm{~m} / \mathrm{s}$ \\
\hline Sinop & $\begin{array}{l}2.15 \mathrm{~m} / \mathrm{s} \text { between the hours of } \\
05: 00 \text { and } 06: 00 \text { in } 2006 \text { year }\end{array}$ & $\begin{array}{l}3.89 \mathrm{~m} / \mathrm{s} \text { between the hours of } \\
13: 00 \text { and } 14: 00 \text { in } 2007 \text { year. }\end{array}$ & $2.93 \mathrm{~m} / \mathrm{s}$ \\
\hline
\end{tabular}

The wind speed data in time-series format is usually arranged in the frequency distribution format since it is more convenient for statistical analysis. Therefore, the available time-series data were translated into frequency distribution format. The probability density distribution of actual data and the theoretical frequency values calculated from the Weibull and Rayleigh distributions are determined [8, 11-14]. The yearly probability density and the cumulative distributions are seen in Figure 4 for ten years. It is seen that all the curves have a similar tendency of wind speeds on probability and cumulative density.

The Weibull and Rayleigh approximations of the actual probability distribution of wind speeds are shown in Figure 5, while a comparison of the two approximations is given in Table 4. In Figure 5, the probability distribution of the actual data, the Weibull probability distribution, and the Rayleigh probability distribution are plotted versus the wind speed according to the average of ten years data. 

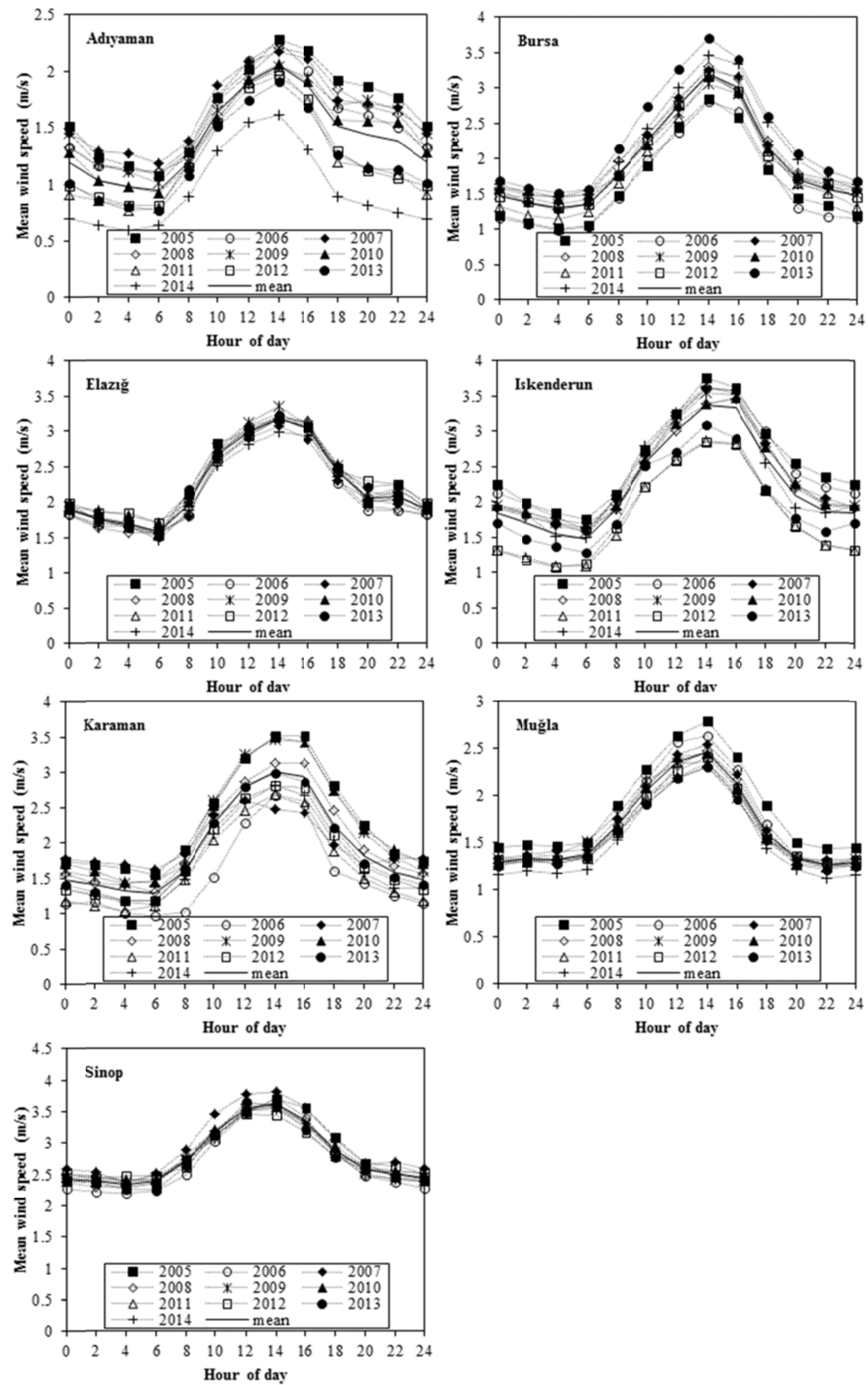

Figure 3. Diurnal variation of mean wind speed for the period of 2005-2014 

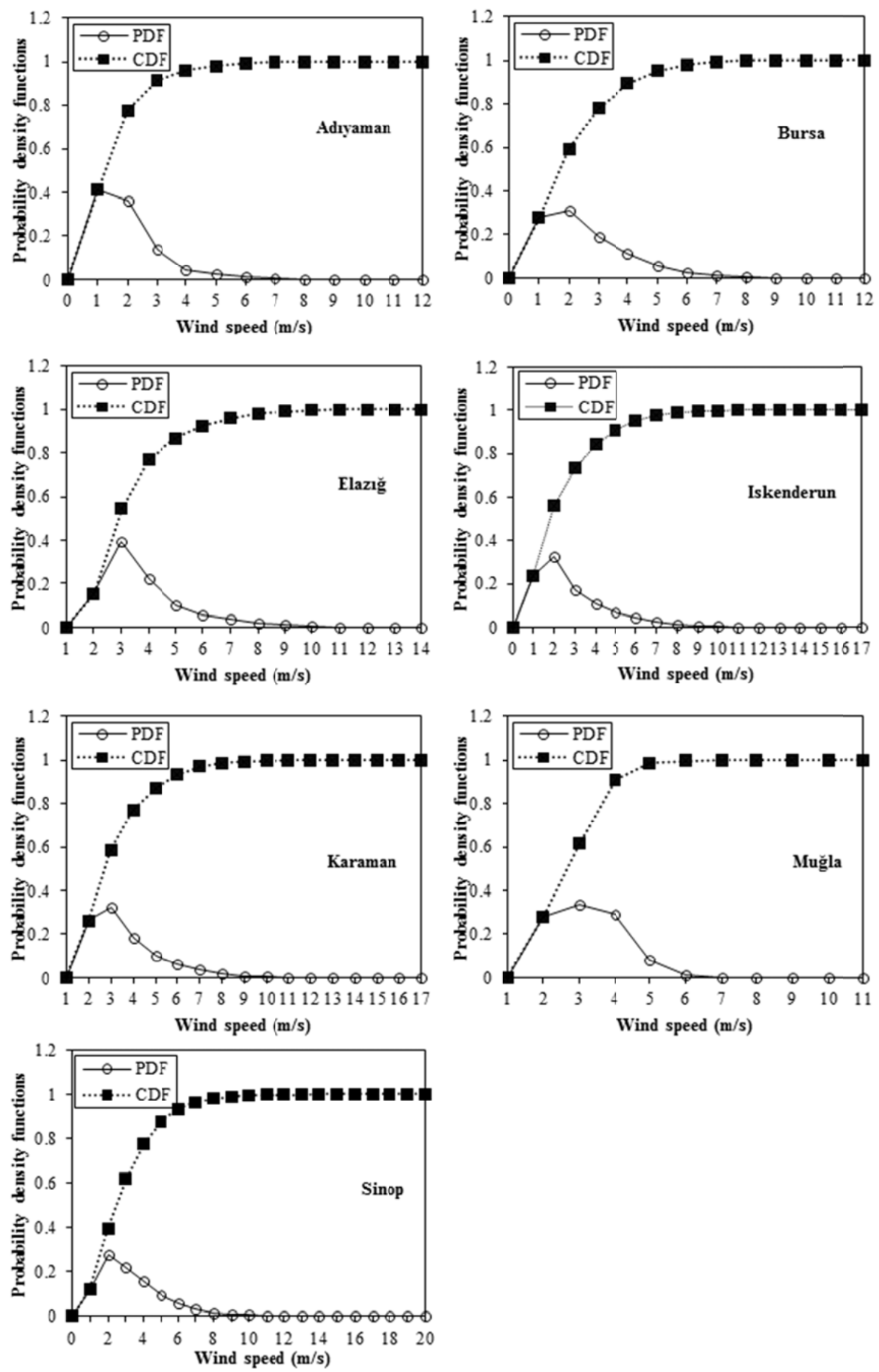

Figure 4. The wind speed probability density and cumulative probability distributions for whole years, derived from the measured hourly time-series 

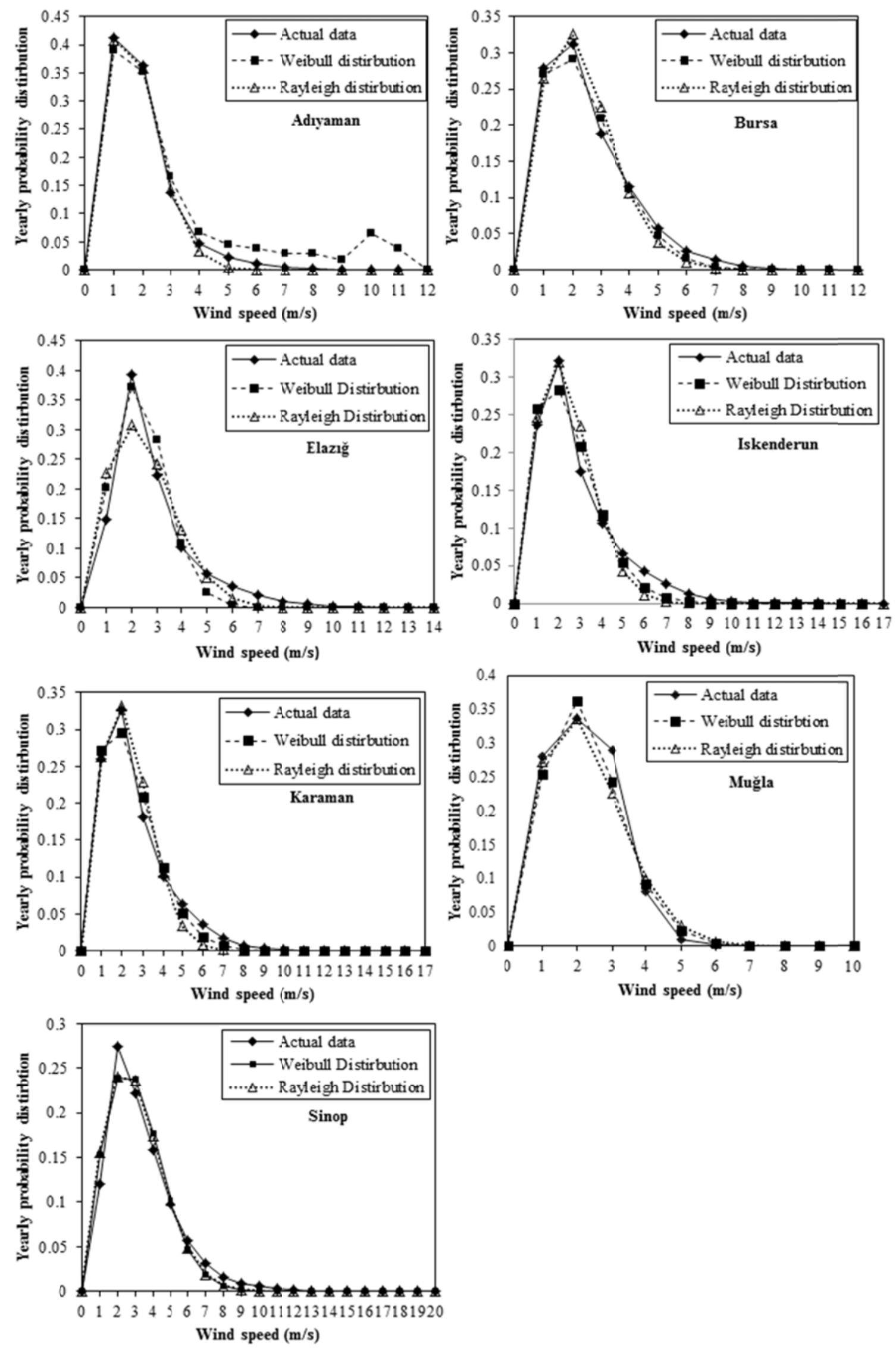

Figure 5. The comparison of Weibull and Rayleigh approximations with the actual probability distribution of wind speeds 
Table 4. $\mathrm{R}^{2}$, RMSE and $\chi^{2}$ values according to Weibull and Rayleigh distributions

\begin{tabular}{|c|c|c|c|c|c|c|}
\hline \multirow{2}{*}{$\begin{array}{c}\text { Adryaman } \\
\text { Year }\end{array}$} & \multicolumn{3}{|c|}{ Weibull Da ġlım } & \multicolumn{3}{|c|}{ Rayleigh Dağilmu } \\
\hline & $\mathbf{R}^{2}$ & RMSE & $i$ & $\mathrm{R}^{2}$ & RMSE & $x^{2}$ \\
\hline 2005 & 0.992 & 0.000103 & 0.000253 & 0.984 & 0.000104 & 0.000229 \\
\hline 2006 & 0.989 & 0.000049 & 0.000122 & 0.968 & 0.000081 & 0.000181 \\
\hline 2007 & 0.992 & 0.000073 & 0.000178 & 0.985 & 0.000125 & 0.000276 \\
\hline 2008 & 0995 & 0.000074 & 0.000181 & 0.984 & 0.000124 & 0.000273 \\
\hline 2009 & 0.986 & 0.000101 & 0.000243 & 0.959 & 0.000128 & 0.000279 \\
\hline 2010 & 0.971 & 0.000037 & 0.000091 & 0.918 & 0.000065 & 0.000143 \\
\hline 2011 & 0.951 & 0.000011 & 0.000028 & 0.916 & 0.000080 & 0.000182 \\
\hline 2012 & 0.985 & 0.000032 & 0.000085 & 0.971 & 0.000036 & 0.000082 \\
\hline 2013 & 0990 & 0.000040 & 0.000113 & 0.981 & 0.000042 & 0.000097 \\
\hline 2014 & 0.992 & 0.000025 & 0.000112 & 0.981 & 0.000106 & 0.000248 \\
\hline Bursa & & eibull Dağgl & & & aykigh Dağ & \\
\hline Year & $\mathrm{R}^{2}$ & RMSE & $x$ & $\mathrm{R}^{2}$ & RMSE & $\dot{x}$ \\
\hline 2005 & 0.977 & 0.000182 & 0.000455 & 0.884 & 0.000940 & 0.002090 \\
\hline 2006 & 0976 & 0.000187 & 0.000458 & 0.886 & 0.000915 & 0.002012 \\
\hline 2007 & 0.986 & 0.000082 & 0.000197 & 0.981 & 0.000110 & 0.000240 \\
\hline 2008 & 0.865 & 0.002046 & 0.005001 & 0.658 & 0.002090 & 0.004599 \\
\hline 2009 & 0.988 & 0.000077 & 0.000193 & 0.984 & 0.000106 & 0.000236 \\
\hline 2010 & 0.983 & 0.000105 & 0.000256 & 0967 & 0.000200 & 0.000441 \\
\hline 2011 & 0.997 & 0.000018 & 0.000046 & 0.984 & 0.000114 & 0.000257 \\
\hline 2012 & 0.990 & 0.000059 & 0.000144 & 0976 & 0.000145 & 0.000320 \\
\hline 2013 & 0.965 & 0.000179 & 0.000447 & 0.947 & 0.000269 & 0.000597 \\
\hline 2014 & 0.950 & 0.000305 & 0.000784 & 0950 & $0.000: 09$ & 0.000695 \\
\hline Ehnis & & eibull Dagih & & & aykigh Dagin & \\
\hline Year & $\overline{\mathbf{R}^{i}}$ & RMSE & $\bar{x}$ & $\mathbf{R}^{2}$ & RMSE & $i$ \\
\hline 2005 & 0.927 & 0.000509 & 0.001204 & 0.862 & 0.000971 & 0.002104 \\
\hline 2006 & 0.909 & 0.000707 & 0.001697 & 0.844 & 0.001205 & 0.002630 \\
\hline 2007 & 0.941 & 0.000429 & 0.001015 & 0.871 & 0.000941 & 0.002039 \\
\hline 2008 & 0.934 & 0.000479 & 0.001150 & 0.884 & 0.000852 & 0.001860 \\
\hline 2009 & 0909 & 0.000588 & 0.001410 & 0.885 & 0.000744 & 0.001624 \\
\hline 2010 & 0.901 & 0.000638 & 0.001489 & 0.853 & 0.000550 & 0.002046 \\
\hline 2011 & 0975 & 0.000140 & 0.000332 & 0.954 & 0.000263 & 0.000570 \\
\hline 2012 & 0943 & 0.000302 & 0.000713 & 0.938 & 0.000332 & 0.000720 \\
\hline 2013 & 0.958 & 0.000168 & 0.000397 & 0.962 & 0.000202 & 0.000437 \\
\hline 2014 & 0.950 & 0.000236 & 0.000558 & 0.947 & 0.000313 & 0.000679 \\
\hline Ilke nder un & & bull Distribv & & & leigh Distrib & \\
\hline Year & $\bar{R}$ & RMSE & $x$ & $\mathrm{R}^{2}$ & RMSE & $\dot{x}$ \\
\hline 2005 & 0.906 & 0.004171 & 0.009732 & 0.900 & 0.000443 & 0.000954 \\
\hline 2006 & 0.924 & 0.000312 & 0.000707 & 0917 & 0.000340 & 0.000722 \\
\hline 2007 & $09: 9$ & 0.000282 & 0.000659 & 0.919 & 0.000374 & 0.000806 \\
\hline 2008 & 0.922 & 0.000403 & 0.000952 & 0.919 & 0.000419 & 0.000908 \\
\hline 2009 & 0.922 & 0.000395 & 0.000933 & 0.919 & 0.000412 & 0.000891 \\
\hline 2010 & 0916 & 0.000435 & 0.001029 & 0910 & 0.000470 & 0.001017 \\
\hline 2011 & 0.994 & 0.000041 & 0.000103 & 0957 & 0.000295 & 0.000654 \\
\hline 2012 & 0.994 & 0.000037 & 0.088290 & 0940 & 0.000372 & 0.000806 \\
\hline 2013 & 0995 & 0.000022 & 0.051670 & 0.966 & 0.000175 & 0.000377 \\
\hline 2014 & 0.994 & 0.000026 & 0.059140 & 0959 & 0.000177 & 0.000378 \\
\hline Karaman & & ểnull Dagh & & & aykigh Dign & \\
\hline Year & $\mathbf{R}^{2}$ & RMSE & $i$ & $\mathbf{R}^{2}$ & RMSE & $i$ \\
\hline 2005 & 0.992 & 0.030950 & 0.070160 & 0.942 & 0.000249 & 0.000529 \\
\hline 2006 & 0.972 & 0.000150 & 0.000349 & 0969 & 0.000165 & 0.000356 \\
\hline 2007 & 0.939 & 0.000313 & 0.000741 & 0936 & 0.000366 & 0.000705 \\
\hline 2008 & 0.963 & 0.000190 & 0.000444 & 0.952 & 0.000251 & 0.000542 \\
\hline 2009 & 0.965 & 0.000169 & 0.000394 & 0.944 & 0.000270 & 0.000582 \\
\hline 2010 & 0.974 & 0.000128 & 0.000299 & 0.969 & 0.000150 & 0.000324 \\
\hline 2011 & 0.981 & 0.000161 & 0.000413 & 0980 & 0.000173 & 0.000389 \\
\hline 2012 & 0.988 & 0.000085 & 0.000217 & 0.969 & 0.000221 & 0.000497 \\
\hline 2013 & 0.993 & 0.000041 & 0.099160 & 0.963 & 0.000215 & 0.000470 \\
\hline 2014 & 0.989 & 0.066030 & 0.000158 & 0,970 & 0.000192 & 0.000419 \\
\hline Muğla & & ibull Dağhtr & & & ykigh Dainh & \\
\hline Year & $\mathbf{R}^{2}$ & RMSE & $z^{2}$ & $\mathbf{R}^{2}$ & RMSE & $x^{2}$ \\
\hline 2005 & 0.930 & 0.000506 & 0.001349 & 0.929 & 0.000513 & 0.001173 \\
\hline 2006 & 0.900 & 0.000799 & 0.002236 & 0.875 & 0.000993 & 0.002316 \\
\hline 2007 & 0.981 & 0.000185 & 0.000493 & 0952 & 0.000478 & 0.001092 \\
\hline 2008 & 0.976 & 0.000252 & 0.000704 & 0961 & 0.000418 & 0.000975 \\
\hline 2009 & 0.985 & 0.000147 & 0.000378 & 0964 & 0.000344 & 0.000774 \\
\hline 2010 & 0.975 & 0.000257 & 0.00072 & 0.964 & 0.000420 & 0.000979 \\
\hline 2011 & 0.981 & 0.000212 & 0.000635 & 0934 & 0.000757 & 0.001816 \\
\hline 2012 & 0.983 & 0.000163 & 0.000407 & 0963 & 0.000367 & 0.000815 \\
\hline 2013 & 0.977 & 0.000243 & 0.000647 & 0970 & 0.000317 & 0.000725 \\
\hline 2014 & 0.983 & 0.000188 & 0.000528 & 0976 & 0.000271 & 0.000632 \\
\hline Sinop & & ibull Dag̀ilm & & & leigh Daghtn & \\
\hline Year & $\mathbf{R}^{2}$ & RMSE & $i$ & $R^{2}$ & RMSE & $x^{2}$ \\
\hline 2005 & 0.982 & 0.000060 & 0.000140 & 0.969 & 0.000107 & 0.000231 \\
\hline 2006 & 0.994 & 0.000016 & 0,000036 & 0.930 & 0.000209 & 0.000439 \\
\hline 2007 & 0.969 & 0.000110 & 0.000256 & 0.966 & 0.000120 & 0.000257 \\
\hline 2008 & 0.969 & 0.000066 & 0.000155 & 0.981 & 0.000069 & 0.000149 \\
\hline 2009 & 0.962 & 0.000146 & 0.000340 & 0.962 & 0.000147 & 0.000316 \\
\hline 2010 & 0.966 & 0.000128 & 0.000298 & 0.965 & 0.000135 & 0.000290 \\
\hline 2011 & 0.937 & 0.000258 & 0.000597 & 0.931 & 0.000284 & 0.000608 \\
\hline 2012 & 0957 & 0.000191 & 0.000446 & 0.937 & 0.000284 & 0.000612 \\
\hline 2013 & 0.961 & 0.000140 & 0.000314 & 0.955 & 0.000164 & 0.000345 \\
\hline 2014 & 0.941 & 0.000237 & 0.000547 & 0.936 & 0.000258 & 0.000552 \\
\hline
\end{tabular}


The values obtained according to Weibull and Rayleigh distributions of the statistical parameters as $\mathrm{R}^{2}$, RMSE, and $\chi^{2}$ are given in Table 4 . At the Weibull distribution, the $\mathrm{R}^{2}$ value is between 0.66-0.99 and at the Rayleigh distribution is between 0.65-0.98. As can be seen in Table 4, the highest $\mathrm{R}^{2}$ value is obtained by using the Weibull distribution. However, the results have shown that the RMSE and $\chi^{2}$ values of the Weibull distribution are lower than the values obtained for the Rayleigh distribution. As a result, the Weibull approximation is found to be the most accurate distribution according to the highest value of $\mathrm{R}^{2}$ and the lowest values of RMSE and $\chi^{2}$.

Figure 6 shows the monthly change in the $\mathrm{R}^{2}$ obtained from the Weibull and Rayleigh distributions for the selected cities using the ten-year data. The $\mathrm{R}^{2}$ values are ranged from 0.89 to 0.99 in the Weibull distribution and 0.54 to 0.98 in the Rayleigh distribution. Because the $\mathrm{R}^{2}$ value is closer to 1 in the Weibull distribution, it is understood that the Weibull distribution is more suitable for modeling the wind data for the studied cities. 

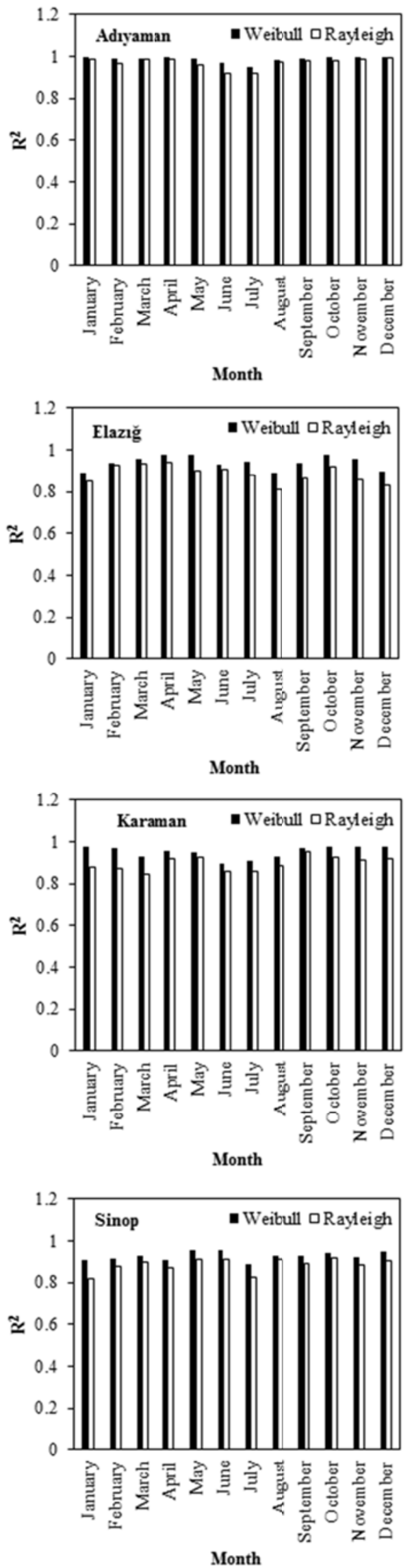
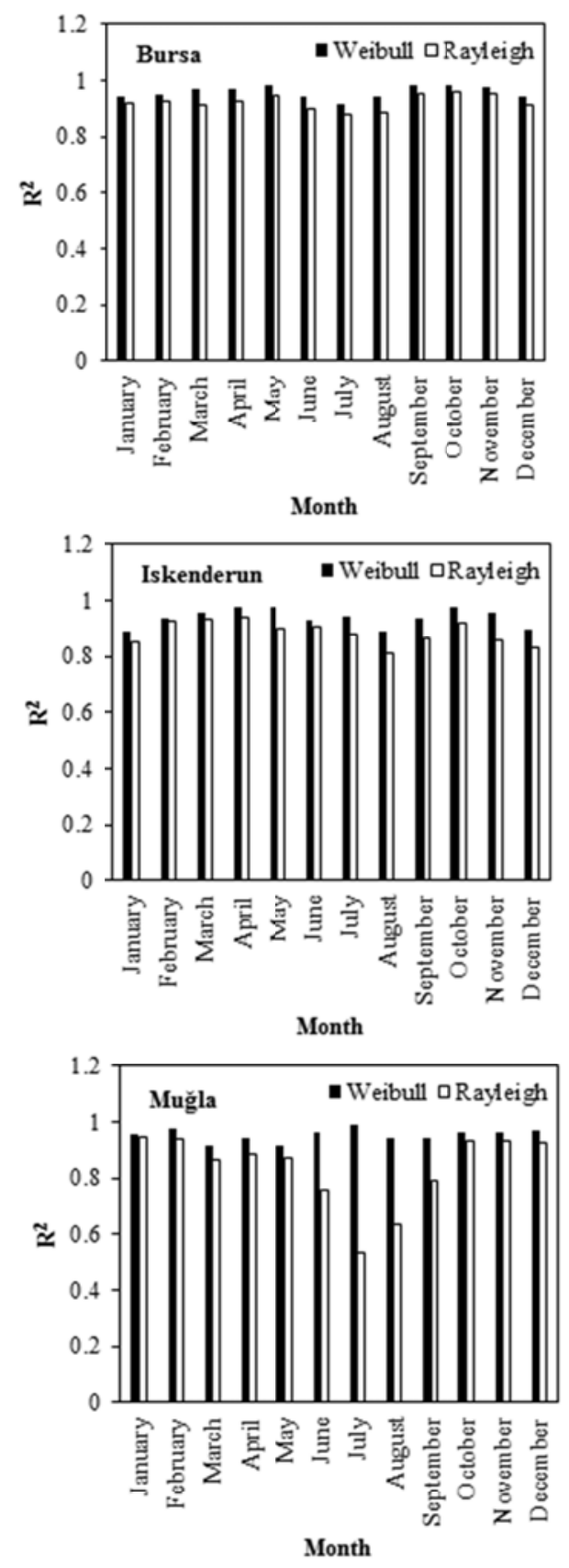
Figure 6. The change of $\mathrm{R}^{2}$ values obtained from Weibull and Rayleigh distribution to months

The Weibull distribution parameters and the Rayleigh distribution parameters are given in Table 5 and Table 6 according to years, respectively. Table 5 shows the yearly values of the two Weibull parameters, the scale parameter $\mathrm{c}(\mathrm{m} / \mathrm{s})$ and shape parameter $\mathrm{k}$ (dimensionless), calculated from the long term wind data for the studied site. The values of $c$ and $k$ were determined using the method described in Section 3.1 [6-18]. It is clear that the parameter $k$ has a much smaller, temporal variation than the parameter $c$. In Weibull distribution, the range of $\mathrm{k}$ is between 1.167 (Muğla in 2014) and 2.702 (Elazığ in 2007), while the c value varies from 1.58 (Adiyaman in 2014) to $3.69 \mathrm{~m} / \mathrm{s}$ (Sinop in 2007). In Rayleigh distribution, the values of $c$ changed to 1.563 from $3.717 \mathrm{~m} / \mathrm{s}$. In Weibull and Rayleigh distribution, the lowest value of the scale parameter is found in 2014 at Adryaman, while the highest value is occurred in 2007 at Sinop. The mean wind intensity and standard deviation values are important in predicting shape and scale parameters. The monthly mean wind speed values $v_{m}$ and standard deviations $\sigma$ are presented in Table 5 and 6 for the studied sites. Most of the yearly mean wind speed values are between 2 and $3 \mathrm{~m} / \mathrm{s}$, but only a few are over $3.0 \mathrm{~m} / \mathrm{s}$ and under $2.0 \mathrm{~m} / \mathrm{s}$. While Sinop in 2007 has the highest mean wind speed value with $3.276 \mathrm{~m} / \mathrm{s}$, at Adryaman in 2014 exhibits the minimum mean wind speed value of $1.40 \mathrm{~m} / \mathrm{s}$. The maximum mean velocity $\left(V_{\max }\right)$ in the Weibull distribution ranges from 2.131 to $5.464 \mathrm{~m} / \mathrm{s}$ and the mean power density $(P)$ ranges from 2.737 to $39.203 \mathrm{~W} / \mathrm{m}^{2}$. In the Rayleigh distribution, $V_{\max }$ and $P$ varies from 2.210 to $5.257 \mathrm{~m} / \mathrm{s}$ and 2.873 to $41.656 \mathrm{~W} / \mathrm{m}^{2}$, respectively. The mean wind velocity is determined between 1.725 and $2.95 \mathrm{~m} / \mathrm{s}$ for Weibull distribution and 1.723 and $3.055 \mathrm{~m} / \mathrm{s}$ for Rayleigh distribution. At the Weibull distribution, the highest mean power density is 33.317 $\mathrm{W} / \mathrm{m}^{2}$ in Sinop and the lowest mean power density is $5.777 \mathrm{~W} / \mathrm{m}^{2}$ in Adiyaman. At the Rayleigh distribution, the highest power density is determined as $33.443 \mathrm{~W} / \mathrm{m}^{2}$ in Sinop and the lowest mean power density as $5.629 \mathrm{~W} / \mathrm{m}^{2}$ in Adiyaman. Generally, the highest mean wind speed and power density values was determined in Sinop, and the lowest mean wind speed and power density values in Adiyaman. 
Table 5. Weibull distribution parameters

\begin{tabular}{|c|c|c|c|c|c|c|c|}
\hline Adryat & & & & & & & \\
\hline $\begin{array}{l}\text { Year } \\
2005\end{array}$ & $\mathbf{k}$ & $c(\mathrm{~m} / \mathrm{s})$ & $V_{0}(m / y)$ & $\sigma(m / y)$ & $V_{\operatorname{mos}}(m / s)$ & $V_{m=}(n / s)$ & $\begin{array}{l}P_{*}\left(\mathrm{WV} / \mathrm{m}^{2}\right) \\
72245\end{array}$ \\
\hline 2005 & 1.980 & 2.120 & 1.879 & 0.990 & 1.486 & 3.015 & 7245 \\
\hline 2006 & 1.865 & 2.037 & 1809 & 1.007 & 1350 & 3.011 & 6.890 \\
\hline 2007 & 1.814 & 2.019 & 1.795 & 1.024 & 1.299 & 3.041 & 6943 \\
\hline 2008 & 1.819 & 1.997 & 1.775 & 1.010 & 1.288 & 3.002 & 6.694 \\
\hline 2009 & 2.142 & 2.074 & 1.837 & 0.902 & 1.547 & 2.822 & 6280 \\
\hline 2010 & 1.870 & 1.913 & 1.698 & 0.943 & 1.270 & 2.822 & 5.683 \\
\hline 2011 & 2.170 & 1.957 & 1.733 & 0.841 & 1.472 & 2.644 & 5.211 \\
\hline 2012 & 1.959 & 1.900 & 1.685 & 0.897 & 1320 & 2.722 & 5.283 \\
\hline 2013 & 1.978 & 1.848 & 1.638 & 0.864 & 1.294 & 2.631 & 4.805 \\
\hline 2014 & 2.182 & 1.581 & 1.400 & 0.677 & 1.1.194 & 2.131 & 2.737 \\
\hline mean & 1.978 & 1.945 & 1.725 & 0.916 & 1.352 & 2.784 & 5.777 \\
\hline Bursa & & & & & & & \\
\hline Year & $\mathbf{k}$ & $c(\mathrm{~m} / \mathrm{s})$ & $V_{n}(m / s)$ & $\sigma(m / s)$ & $V_{\operatorname{mat}}(m / s)$ & $V_{\operatorname{man}}(n / s)$ & $P_{n}\left(W / m^{2}\right)$ \\
\hline 2005 & 1.443 & 2.047 & 1.857 & 1.302 & 0.903 & 3.740 & 11.185 \\
\hline 2006 & 1.431 & 1.989 & 1.807 & 1.281 & 0.860 & 3.664 & 10.424 \\
\hline 2007 & 1.862 & 2.630 & 2335 & 1.302 & 1.739 & 3.891 & 15.871 \\
\hline 2008 & 2.177 & 3.125 & 2.768 & 1.340 & 2356 & 4.216 & 22.623 \\
\hline 2009 & 1.874 & 2.554 & 2.697 & 1.257 & 1.700 & 3.763 & 14.428 \\
\hline 2010 & 1.760 & 2.563 & 2282 & 1.338 & 1.591 & 3.944 & 15.789 \\
\hline 2011 & 1.786 & 2.503 & 2227 & 1.288 & 1.582 & 3.811 & 14.421 \\
\hline 2012 & 1.781 & 2.634 & 2343 & 1.360 & 1.658 & 4.019 & 16.873 \\
\hline 2013 & 1.770 & 2.869 & 2554 & 1.490 & 1.793 & 4.399 & 21999 \\
\hline 2014 & 2.048 & 2.825 & 2503 & 1.280 & 2.037 & 3.940 & 17.704 \\
\hline mean & 1.793 & 2.574 & 2337 & 1.324 & 1.622 & 3.939 & 16.132 \\
\hline Ebaris & & & & & & & \\
\hline Year & k & $c(m / s)$ & $V_{m}(m / y)$ & $\sigma(m / s)$ & $V_{\bmod }(m / s)$ & $V_{m n}(n / s)$ & $\mathrm{P}_{\mathrm{w}}\left(\mathrm{WW} / \mathrm{m}^{2}\right)$ \\
\hline 2005 & $\begin{array}{l}2.662 \\
2.691\end{array}$ & $\begin{array}{l}2.598 \\
2.509\end{array}$ & $\begin{array}{l}2309 \\
2231\end{array}$ & $\begin{array}{l}0.934 \\
0.893\end{array}$ & $\begin{array}{l}2.176 \\
2.111\end{array}$ & $\begin{array}{l}3.206 \\
3.084\end{array}$ & $\begin{array}{l}10.107 \\
9.053\end{array}$ \\
\hline $\begin{array}{l}2006 \\
2007\end{array}$ & $\begin{array}{l}2.691 \\
2.702\end{array}$ & $\begin{array}{l}2.509 \\
2.548\end{array}$ & $\begin{array}{l}2231 \\
2266\end{array}$ & $\begin{array}{l}0.893 \\
0.904\end{array}$ & $\begin{array}{l}2.111 \\
2.147\end{array}$ & $\begin{array}{l}3.084 \\
3.127\end{array}$ & $\begin{array}{l}9.053 \\
9.456\end{array}$ \\
\hline 2008 & 2.579 & 2.534 & 2250 & 0.936 & 2.095 & 3.166 & 9.562 \\
\hline 2009 & 2.377 & 2.658 & 2356 & 1.054 & 2.113 & 3.436 & 11.650 \\
\hline 2010 & 2.600 & 2.568 & 2281 & 0.942 & 2.131 & 3.199 & 9905 \\
\hline 2011 & 2.324 & 2.882 & 2553 & 1.166 & 2.263 & 3.764 & 15.098 \\
\hline 2012 & 2.166 & 2.835 & 2511 & 1.221 & 2.130 & 3.834 & 15237 \\
\hline 2013 & 2.166 & 2.898 & 2566 & 1.248 & 2.177 & 3.919 & 16271 \\
\hline 2014 & 2.258 & 2.739 & 2.426 & 1.137 & 2.114 & 3.627 & 13264 \\
\hline mean & 2.453 & 2.677 & 2375 & 1.043 & 2.146 & 3.436 & 11960 \\
\hline Iskend & & & & & & & \\
\hline Year & $\mathbf{k}$ & $c(\mathrm{~m} / \mathrm{s})$ & $V_{n}(m / s)$ & $\sigma(\mathrm{m} / \mathrm{y})$ & $\mathrm{V}_{\operatorname{mat}}(\mathrm{m} / \mathrm{s})$ & $V_{m n}(n / s)$ & $\mathrm{P}_{*}\left(\mathrm{~W} / \mathrm{m}^{5}\right)$ \\
\hline 2005 & 1.846 & 2.991 & 2.657 & 1.493 & 1960 & 4.452 & 23.877 \\
\hline 2006 & 1.823 & 2.914 & 2590 & 1.472 & 1. .834 & 4.375 & 22.428 \\
\hline 2007 & 1.710 & 2.771 & 2.471 & 1.488 & 1.658 & 4.358 & 21.018 \\
\hline 2008 & 1.878 & 2.719 & 2.414 & 1.335 & 1.814 & 4.001 & 17566 \\
\hline 2009 & 1.877 & 2.748 & 2.439 & $\begin{array}{l}1.350 \\
1.350\end{array}$ & 1.832 & 4.045 & 18.142 \\
\hline 2010 & 1.840 & 2.743 & 2.436 & 1.373 & 1.791 & 4.091 & 18.477 \\
\hline 2011 & 1.636 & 2.367 & 2.118 & 1.327 & 1329 & 3.855 & 13997 \\
\hline 2012 & 1.543 & 2.300 & 2.069 & 1.369 & 1.169 & 3.942 & 14.157 \\
\hline 2013 & 1.665 & 2.658 & 2375 & 1.465 & 1532 & 4.269 & 19309 \\
\hline 2014 & 1.6378 & 2.781 & 2.488 & 1.558 & 1.563 & 2.527 & 22.679 \\
\hline mean & 1.745 & 2.699 & 2.406 & 1.423 & 1.653 & 3.991 & 17.016 \\
\hline Mfujla & & & & & & & \\
\hline Year & $\mathrm{k}$ & $c(m / s)$ & $V_{m}(m / g)$ & $\sigma(\mathrm{m} / \mathrm{s})$ & $V_{m a t}(m / s)$ & $\mathrm{V}_{\mathrm{mm}}(\mathrm{m} / \mathrm{s})$ & $P_{*}\left(W / m^{2}\right)$ \\
\hline 2005 & 1.941 & 2.823 & 2.504 & 1.344 & 1945 & 4.065 & 17537 \\
\hline 2006 & 1.741 & 2.599 & 2315 & 1.371 & 1591 & 4.032 & 15.676 \\
\hline 2007 & 2.363 & 2.583 & 2.289 & 1.030 & 2.046 & 3.348 & 11.209 \\
\hline 2008 & 2.246 & 2.466 & 2.185 & 1.029 & 1.897 & 3.275 & 10.157 \\
\hline 2009 & 2.309 & 2.533 & 2244 & 1.031 & 1981 & 3.318 & 10.755 \\
\hline 2010 & 2.244 & 2.497 & 2.211 & 1.042 & 1920 & 3.316 & 10542 \\
\hline 2011 & 2.416 & 2.459 & 2.180 & 0.961 & 1971 & 3.156 & 9515 \\
\hline 2012 & 2.327 & 2.458 & 2.178 & 0.993 & 1931 & 3.209 & 9.778 \\
\hline 2013 & 2.172 & 2.399 & 2.124 & 1.031 & 1.806 & 3.239 & 9.615 \\
\hline 2014 & 1.167 & 2.328 & 2.061 & 1.895 & 1.750 & 3.147 & 8.805 \\
\hline mean & 2.093 & 2.514 & 2.229 & 1.173 & 1.884 & 3.411 & 11.359 \\
\hline Karam & & & & & & & \\
\hline Year & $\mathrm{k}$ & $c(\mathrm{~m} / \mathrm{s})$ & $V_{-}(m / s)$ & $\sigma(\mathrm{m} / \mathrm{s})$ & $V_{\bmod }(m / s)$ & $V_{m=}(m s)$ & $P_{*}\left(W / m^{2}\right)$ \\
\hline 2005 & 1.552 & 2.632 & 2.366 & 1.556 & 1.353 & 4.485 & 18.102 \\
\hline 2006 & 1.882 & 2.621 & 2326 & 1.284 & 1.753 & 3.849 & 13526 \\
\hline 2007 & 1.897 & 2.797 & 2.482 & 1.360 & 1.885 & 4.086 & 15.422 \\
\hline 2008 & 1.766 & 2.602 & 2310 & 1.275 & 1.740 & 3.822 & 13239 \\
\hline 2009 & 1.707 & 2.715 & 2.442 & 1.606 & 1396 & 4.628 & 19.883 \\
\hline 2010 & 1.859 & 2.746 & 2.437 & 1.345 & 1.836 & 4.033 & 15556 \\
\hline 2011 & 1.920 & 2.276 & 2.047 & 1.346 & 1.170 & 3.879 & 11.712 \\
\hline 2012 & 1.745 & 2.430 & 2.157 & 1.191 & 1.625 & 3.570 & 10.788 \\
\hline 2013 & 1.672 & 2.578 & 2.318 & 1.524 & 1.325 & 4.393 & 17.009 \\
\hline 2014 & 1.715 & 2.440 & 2.166 & 1.195 & 1.632 & 3.584 & 10919 \\
\hline mean & 1.772 & 2.584 & 2.305 & 1.368 & 1.571 & 4.033 & 14.616 \\
\hline Sinop & & & & & & & \\
\hline Year & k & $c(\mathrm{~m} / \mathrm{s})$ & $V_{m}(m / g)$ & $\sigma(\mathrm{m} / \mathrm{s})$ & $V_{m a d}(m / s)$ & $V_{m=n}(m / l)$ & $P_{*}\left(\mathrm{~W} / \mathrm{m}^{2}\right)$ \\
\hline 2005 & 1.791 & 32.295 & 2.931 & 1.692 & 2.088 & 5.007 & 33.049 \\
\hline 2006 & 1.527 & 3.158 & 2.845 & 1.900 & 1.574 & 5.096 & 37213 \\
\hline 2007 & 2.092 & 3.698 & 3.276 & 1.644 & 2.711 & 5.464 & 39.203 \\
\hline 2008 & 1.949 & 3.499 & 3.103 & 1.660 & 2.419 & 5.027 & 35.745 \\
\hline 2009 & 2.027 & 3.485 & 3.088 & 1.594 & 2.492 & 4.889 & 33.855 \\
\hline 2010 & 2.078 & 3518 & 3.116 & 1.573 & 2566 & 4.866 & 33975 \\
\hline 2011 & 2.151 & 3.461 & 3.065 & 1.500 & 2588 & 4.698 & 31309 \\
\hline 2012 & 2.287 & 3.405 & 3.016 & 1.397 & 2.648 & 4.481 & 28.298 \\
\hline 2013 & 2.167 & 3383 & 2.996 & 1.457 & 2.543 & 4.574 & 29.046 \\
\hline 2014 & 2.137 & 3.460 & 2.064 & 1.509 & 2576 & 4.7140 & 31.482 \\
\hline mean & 2.020 & 3.436 & 2.950 & 1.593 & 2.420 & 9.124 & 33.317 \\
\hline
\end{tabular}


Table 6. Rayleigh distribution parameters

\begin{tabular}{|c|c|c|c|c|c|c|}
\hline \multicolumn{7}{|c|}{ Adngaman } \\
\hline Year & $c(m / 2)$ & $V_{m}(m / s)$ & $\sigma(m / s)$ & $V_{\text {mat }}(m /)$ & $V_{\max }(m / s)$ & $P_{2}\left(\mathrm{~W} / \mathrm{m}^{2}\right)$ \\
\hline 2005 & 2.119 & 1.878 & 0.981 & 1.458 & 2.997 & 7.162 \\
\hline 2006 & 2.038 & 1.806 & 0.944 & 1.441 & 2.883 & 6377 \\
\hline 2007 & 2.021 & 1.791 & 0.936 & 1.429 & 2.859 & 6218 \\
\hline 2008 & 1999 & 1.772 & 0.926 & 1.413 & 2.827 & 6.014 \\
\hline 2009 & 2.081 & 1.844 & 0.964 & 1.472 & 2.944 & 6.786 \\
\hline 2010 & 1918 & 1.700 & 0.888 & 1346 & 2.713 & 5312 \\
\hline 2011 & 1953 & 1.731 & 0.905 & 1381 & 2.763 & 5.612 \\
\hline 2012 & 1.902 & 1.686 & 0.881 & 1.345 & 2.691 & 5.184 \\
\hline 2013 & 1.849 & 1.638 & 0.856 & 1307 & 2.615 & 4.757 \\
\hline 2014 & 1.563 & 1.385 & 0.724 & 1.105 & 2.210 & 2.873 \\
\hline mean & 1944 & 1.723 & 0.900 & 1375 & 2.750 & 5.629 \\
\hline \multicolumn{7}{|l|}{ Bursa } \\
\hline Year & $c(m / s)$ & $V_{-}(m / s)$ & $\sigma(\mathrm{m} / \mathrm{s})$ & $\mathrm{V}_{\mathrm{mad}}(\mathrm{m} / \mathrm{s})$ & $V_{\max }(m / s)$ & $P_{n}(m / s)$ \\
\hline 2005 & 2.121 & 1.879 & $0.982^{\circ}$ & 1.499 & 2999 & 7.674 \\
\hline 2006 & 2.063 & 1.828 & 0.955 & 1.458 & 2917 & 7.062 \\
\hline 2007 & 2.615 & 2.317 & 1.211 & 1.849 & 3.698 & 14.385 \\
\hline 2008 & 3.219 & 2.853 & 1.491 & 2276 & 4553 & 26.846 \\
\hline 2009 & 2.543 & 2.254 & 1.178 & 1.798 & 3597 & 13.240 \\
\hline 2010 & 2.541 & 2251 & 1.177 & 1.796 & 3593 & 13.194 \\
\hline 2011 & 2.501 & 2.216 & 1.158 & 1.768 & 3536 & 12.580 \\
\hline 2012 & 2.627 & 2.328 & 1.217 & 1.858 & 3.716 & 14.593 \\
\hline 2013 & 2.824 & 2.503 & 1.308 & 1997 & 3994 & 18.125 \\
\hline 2014 & 2.835 & 2512 & 1.313 & 2.004 & 4.009 & 18.330 \\
\hline mean & 2.589 & 2.294 & 1.199 & 1.830 & 3.661 & 14.603 \\
\hline \multicolumn{7}{|l|}{ Eharis } \\
\hline Year & $c(\mathrm{~m} / \mathrm{s})$ & $V_{-}(m / s)$ & $\sigma(\mathrm{m} / \mathrm{s})$ & $V_{m}(m / s)$ & $V_{\max }(m / s)$ & $\mathrm{P}_{\mathrm{z}}\left(\mathrm{W} / \mathrm{m}^{2}\right)$ \\
\hline 2005 & 2.749 & 2.436 & 1.273 & 1944 & 3.888 & 15.019 \\
\hline 2006 & 2.685 & 2.379 & 1.243 & 1.898 & 3.797 & 13986 \\
\hline 2007 & 2.693 & 2.387 & 1.247 & 1904 & 3.809 & 14.117 \\
\hline 2008 & 2.662 & 2.359 & 1.233 & 1.882 & 3.765 & 13.636 \\
\hline 2009 & 2.766 & 2.451 & 1.281 & 1956 & 3.912 & 15300 \\
\hline 2010 & 2.738 & 2.427 & 1.268 & 1936 & 3.873 & 14.846 \\
\hline 2011 & 2940 & 2.606 & 1.362 & 2.079 & 4.159 & 18377 \\
\hline 2012 & 2.880 & 2.552 & 1.334 & 2.036 & 4.073 & 17266 \\
\hline 2013 & 2931 & 2.598 & 1.358 & 2.073 & 4.146 & 18.208 \\
\hline 2014 & 2.794 & 2.476 & 1.294 & 1975 & 3.951 & 15.765 \\
\hline mean & 2.784 & 2.467 & 1.289 & 19648 & 3.9376 & 15.652 \\
\hline \multicolumn{7}{|c|}{ Iskender un } \\
\hline Year & $c(\mathrm{~m} / \mathrm{s})$ & $V_{m}(m / s)$ & $\sigma(\mathrm{m} / \mathrm{s})$ & $V_{-1}(m / s)$ & $V_{m a}(\mathrm{~m} / \mathrm{s})$ & $P_{2}\left(W / m^{2}\right)$ \\
\hline 2005 & 2.934 & 2.600 & 1.359 & 2.075 & 4.150 & 20.564 \\
\hline 2006 & 2.853 & 2.529 & 1.747 & 2.017 & 4.035 & 18906 \\
\hline 2007 & 2.690 & 2.384 & 1.553 & 1.902 & 3.805 & 15.848 \\
\hline 2008 & 2.683 & 2.378 & 1.545 & 1.897 & 3.795 & 15.721 \\
\hline 2009 & 2.711 & 2.402 & 1.577 & 1.917 & 3.834 & 16216 \\
\hline 2010 & 2.695 & 2.388 & 1.558 & 1.905 & 3.811 & 15924 \\
\hline 2011 & 2.363 & 2.094 & 1.199 & 1.671 & 3342 & 10.744 \\
\hline 2012 & 2.322 & 2.058 & 1.157 & 1.642 & 3.284 & 10.19 \\
\hline 2013 & 2.645 & 2.344 & 1.502 & 1.870 & 3.741 & 15.006 \\
\hline 2014 & 2.753 & 2.440 & 1.627 & 1.947 & 3.894 & 16983 \\
\hline mean & 2.665 & 2.362 & 1.482 & 1.884 & 3.769 & 15.616 \\
\hline \multicolumn{7}{|l|}{ Muğb } \\
\hline Yal & $c(\mathrm{~m} / \mathrm{s})$ & $V_{m}(m /)$ & $\sigma(\mathrm{m} / \mathrm{s})$ & $V_{m o t}(m / s)$ & $V_{m}(m / s)$ & $P_{x}\left(W / m^{2}\right)$ \\
\hline 2005 & 2.831 & 2509 & 1.311 & 2.002 & 4.004 & 17.124 \\
\hline 2006 & 2.653 & 2351 & 1.229 & 1.876 & 3.752 & 14.091 \\
\hline 2007 & 2.572 & 2.279 & 1.191 & 1.818 & 3.637 & 12.837 \\
\hline 2008 & 2.454 & 2.175 & 1.137 & 1.735 & 3.471 & 11.158 \\
\hline 2009 & 2.521 & 2.235 & 1.168 & 1.783 & 3.566 & 12.100 \\
\hline 2010 & 2.484 & 2.202 & 1.151 & 1.757 & 3514 & 11.575 \\
\hline 2011 & 2.446 & 2.168 & 1.133 & 1.729 & 3.459 & 11.044 \\
\hline 2012 & 2.445 & 2.166 & 1.132 & 1.728 & 3.457 & 11.027 \\
\hline 2013 & 2.388 & 2.117 & 1.106 & 1.689 & 3378 & 10.284 \\
\hline 2014 & 2.319 & 2.055 & 1.074 & 1.639 & 3.279 & 9.411 \\
\hline mean & 2.511 & 2.226 & 1.163 & 1.776 & 3552 & 12.065 \\
\hline
\end{tabular}

\begin{tabular}{|c|c|c|c|c|c|c|}
\hline \multicolumn{7}{|c|}{ Karaman } \\
\hline Yil & $c(\mathrm{~m} / \mathrm{s})$ & $V_{m}(m / s)$ & $\sigma(\mathrm{m} / \mathrm{s})$ & $V_{m a t}(m / s)$ & $V_{m}(m / s)$ & $P_{z}\left(W / m^{2}\right)$ \\
\hline 2005 & 2.605 & 2.309 & 1.207 & 1.842 & 3.684 & 12.413 \\
\hline 2006 & 2.600 & 2.304 & 1.204 & 1.838 & 3.677 & 12.344 \\
\hline 2007 & 2.767 & 1.772 & 0.926 & $195 \%$ & 3.914 & 5.615 \\
\hline 2008 & 2556 & 2.265 & 1.184 & 1.807 & 3.615 & 11.728 \\
\hline 2009 & 2.654 & 2.352 & 1.229 & 1.876 & 3.753 & 13.127 \\
\hline 2010 & 2.719 & 2.409 & 1.259 & 1922 & 3.845 & 14.111 \\
\hline 2011 & 2.270 & 2.011 & 1.051 & 1.605 & 3.210 & 82109 \\
\hline 2012 & 2.416 & 2.141 & 1.119 & 1.708 & 3.417 & 9904 \\
\hline 2013 & 2.565 & 2.273 & 1.188 & i.s1 & 3.627 & 11.848 \\
\hline 2014 & 2.433 & 2.147 & 1.122 & 1.713 & 3.426 & 9987 \\
\hline mean & 2.558 & 2.198 & 1.149 & 1.808 & 3.617 & 10929 \\
\hline \multicolumn{7}{|l|}{ Sinop } \\
\hline Yil & $c(\mathrm{~m} / \mathrm{s})$ & $V_{m}(\mathrm{~m} / \mathrm{s})$ & $\sigma(\mathrm{m} / \mathrm{s})$ & $V_{m e}(m / s)$ & $V_{\operatorname{man}}(m / s)$ & $P_{n}\left(W / m^{2}\right)$ \\
\hline 2005 & 3.252 & 2.882 & 1.506 & 2.299 & 4599 & 27.893 \\
\hline 2006 & 3.105 & 2.751 & 1.438 & 2.195 & 4391 & 24273 \\
\hline 2007 & 3.717 & 3.294 & 1.722 & 2.628 & 5257 & 41.656 \\
\hline 2008 & 3.490 & 3.093 & 1.616 & 2.468 & 4936 & 34,479 \\
\hline 2009 & 3.490 & 3.093 & 1.617 & 2.468 & 4936 & 34.49 \\
\hline 2010 & 3.537 & 3.135 & 1.638 & 2.501 & 5.002 & 35.899 \\
\hline 2011 & 3.499 & 3.101 & 1.621 & 2.474 & 4949 & 34.757 \\
\hline 2012 & 3.466 & 3.072 & 1.606 & 2.451 & 4903 & 33.791 \\
\hline 2013 & 3.427 & 3.037 & 1.587 & 2.423 & 4.847 & 32.646 \\
\hline 2014 & 3.492 & 3.095 & 1.618 & 2.469 & 4939 & 34546 \\
\hline mean & 3.447 & 3.055 & 1.597 & 2.438 & 4.876 & 33.443 \\
\hline
\end{tabular}




\section{Conclusion}

In this study, the wind power density and wind speed distribution parameters of Turkey's seven regions were statistically analyzed using wind speed data measured between 2005 and 2014 years. Two probability density functions were fitted to the measured probability distributions on a yearly basis. Performances of the probability models were compared to the measured monthly and yearly wind speed values. Weibull and Rayleigh distributions were used for modeling and the success of this modeling process was evaluated according to $\mathrm{R}^{2}$, RMSE and $\chi^{2}$ parameters. The results can be summarized as follows:

(a) The yearly mean wind speed values were mostly between 1.97 and $3.36 \mathrm{~m} / \mathrm{s}$ for selected cities. The maximum value of the yearly mean wind speed was $3.36 \mathrm{~m} / \mathrm{s}$ in Sinop while the minimum value was $1.97 \mathrm{~m} / \mathrm{s}$ in Adiyaman.

(b) At monthly basis, the lowest and the highest wind speed was determined as $1.34 \mathrm{~m} / \mathrm{s}$ at Adiyaman in January of 2014 and as $4.28 \mathrm{~m} / \mathrm{s}$ in February of 2011 at Sinop, respectively.

(c) At daily basis, the lowest and the highest wind speed was obtained as $0.59 \mathrm{~m} / \mathrm{s}$ between 04:00 and 05:00 hours in 2014 year at Adiyaman, as $3.89 \mathrm{~m} / \mathrm{s}$ between 14:00 and 15:00 hours in 2007 year at Sinop, respectively.

(d) The Weibull model was generally better in fitting the measured yearly probability density distributions than the Rayleigh model, to the statistical criteria such as $\mathrm{R}^{2}$, RMSE and $\chi^{2}$. Therefore, it was concluded that it would be better to use the Weibull distribution in the analysis of wind data of the selected cities.

(e) At mean yearly basis, according to the Weibull distribution, the lowest mean wind speed and power density was obtained as $1.725 \mathrm{~m} / \mathrm{s}$ and $5.777 \mathrm{~W} / \mathrm{m}^{2}$ in Adiyaman, respectively. The highest mean speed and power density was determined as $2.95 \mathrm{~m} / \mathrm{s}$ and $33.317 \mathrm{~W} / \mathrm{m}^{2}$ in Sinop. According to the Rayleigh distribution, the lowest and the highest mean speed and the power density was obtained as $1.723 \mathrm{~m} / \mathrm{s}$ and $5.629 \mathrm{~W} / \mathrm{m}^{2}$ in Adiyaman, $3.055 \mathrm{~m} / \mathrm{s}$ and $33.443 \mathrm{~W} / \mathrm{m}^{2}$ in Sinop, respectively.

(f) As a result, monthly average power and yearly mean power densities in studied cities were as small as $100 \mathrm{~W} / \mathrm{m}^{2}$, so that it was not possible to support directly to the network by wind energy systems, it can be used in applications where there was no network access or in rural areas where low power density was required. It has been decided that electricity generation from wind energy was suitable because the mean speed on daily and monthly basis was usually $3 \mathrm{~m} / \mathrm{s}$.

\section{References}

[1] Kaplan, Y.A., Aladag, C., "Comparison of Different Methods in Estimating Weibull Distribution Parameters for Wind Power Application". International Journal of Innovative Research in Science, Engineering and Technology 5(12) 2016 : 232-242. 
[2] Ilk1lic, C., "Wind Energy And Assessment of Wind Energy Potential in Turkey". Renewable and Sustainable Energy Reviews 16 (2012) : 1165- 1173.

[3] Azad, A.K., Rasula, M.G., Alam, M.M., Ameer, Uddinb S.M., Mondal, S.K., "Analysis of Wind Energy Conversion System Using Weibull Distribution”. Procedia Engineering 90 (2014): 725-732.

[4] Dokur, E., Kurban, M., "Wind Speed Potential Analysis Based on Weibull Distribution". Balkan Journal of Electrical \& Computer Engineering 3(4) (2015) : 231235.

[5] Dokur, E., Kurban, M., Ceyhan, S., "Wind Speed Modelling Using Inverse Weibull Distrubition: A Case Study For Bilecik, Turkey". International Journal of Energy Applications and Technologies 3(2) (2016) : 55-59.

[6] İncecik, S., Erdoğmuş, F., "An Investigation of The Wind Power Potential on The Western Coast of Anatolia". Renewable Energy 6 (1995) : 863-865.

[7] Ulgen, K., Hepbasli, A., "Determination of Weibull Parameters for Wind Energy Analysis of Izmir, Turkey.” Int J Energy Res 26 (2002) : 494-506.

[8] Celik, A.N., "A Statistical Analysis of Wind Power Density Based on the Weibull and Rayleigh Models at the Southern Region of Turkey." Renewable Energy 29(4) (2003):593-604.

[9] Karsli, V.M., Gecit, C., "An Investigation on Wind Power Potential of Nurdag1Gaziantep, Turkey". Renew Energy 28 (2003) : 823-830.

[10] Kose, R., Ozgur, M.A., Erbas, O., Tugcu, A., "The Analysis of Wind Data and Energy Potential in Kutahya, Turkey". Renew Sustain Energy Rev 8 (2004) : 277-88.

[11] Akpinar, E.K., Akpinar, S., "Determination of the Wind Energy Potential for MadenElazığ, Turkey”. Energy Conversion and Management 45 (2004): 2901-2914.

[12] Akpinar, E.K., Akpinar, S., "Statistical Analysis of Wind Energy Potential on The Basis of the Weibull And Rayleigh Distribution for Ağın-Elazığ Turkey”. J.Power Energy 218 (2004) : 557-565.

[13] Akpinar, E.K., Akpinar, S., "A Statistical Analysis of Wind Speed Data Used In Installation of Wind Energy Conversion Systems". Energy Conversion and Management 46(4) (2005) : 515-532.

[14] Akpinar, E.K., "A Statistical Investigation of Wind Energy Potential”. Energy Sources, Part A 28 (2006): 807-820.

[15] Genc, A., Erisoglu, M., Pekgor, A., Oturanc, G., Hepbasli, A., Ulgen, K., "Estimation of Wind Power Potential Using Weibull Distribution”. Energ Source 27 (2005) : 809-822.

[16] Gökcek, M., Bayülken, A., Bekdemir, Ş., "Investigation of Wind Characteristics and Wind Energy Potential in Kirklareli, Turkey”. Renewable Energy 32 (2007) : 17391752.

[17] Akdag, S.A., Dinler, A., "A New Method to Estimate Weibull Parameters for Wind Energy Applications”. Energ Convers Manage 50 (2009) : 1761-1766.

[18] Mert, I., Karakus, C., "A Statistical Analysis of Wind Speed Data Using Burr, Generalized Gamma, and Weibull Distributions in Antakya, Turkey”. Turk J Elec Eng \& Comp Sci 23 (2015) : 1571 -1586.

[19] Lun, I.Y.F., Lam, J.C., “A Study of Weibull Parameters Using Long-Term Wind Observations". Renewable Energy 20 (2000) : 145-153. 


\section{Nomenclature}

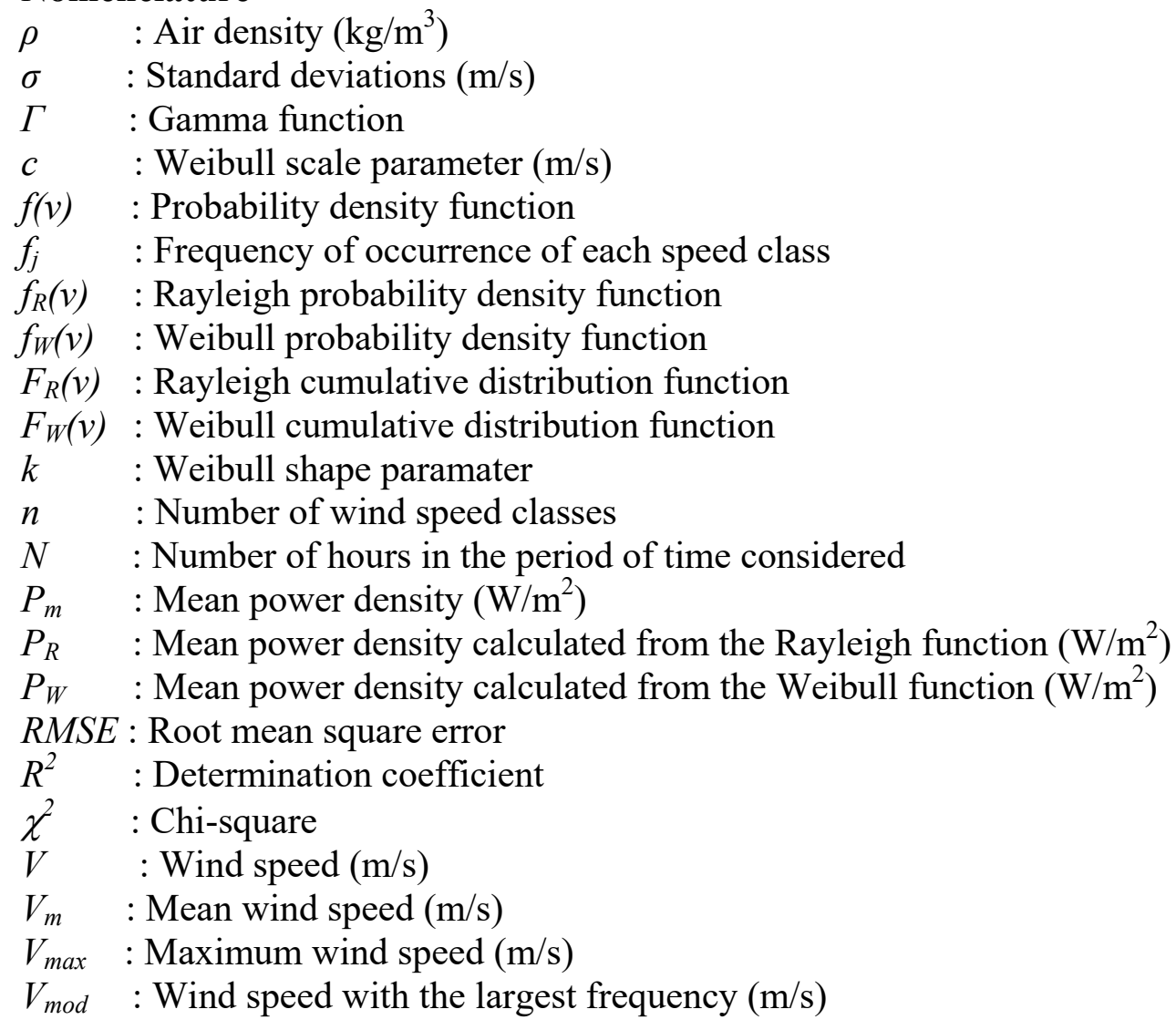

